\title{
ANALISIS PENDIDIKAN SOSIAL ANAK PERSPEKTIF ABDULLAH NASIH ULWAN DALAM KITAB TARBIYAH AL-AWLAD FI AL-ISLAM
}

\author{
1)Ulva Badi' Rohmawati, M.Pd.I, ${ }^{2}$ Sitti Atiyatul Mahfudoh, M.Pd.I \\ IAI Sunan Giri Bojonegoro, IAI Al Khairat Pamekasan \\ Email: ulvabadi@gmail.com, siti.atiyah.m@gmail.com
}

\begin{abstract}
Abstrak: era globalisasi adalah era kemajuan. Diantaranya adalah kemajuan teknologi. Hal ini pasti akan banyak berimbas kepada kehidupan manusia. Utamanya kehidupan dalam bermasyarakat. Tidak dapat dipungkiri kemajuan teknologi sangat memberi dampak kepada kehidupan manusia. Disatu sisi membawa kemajuan, disisi lain membawa perubahan dalam kehidupan bermasyarakat. Pengaruh globalisasi dengan ditandai keterbukaan media semakin membanjiri anak-anak. Anak-anak lebih tertarik dengan gadget dibanding bersosialisasi dengan lingkungan sekitarnya. Padahal masyarakat merupakan salah satu tempat berlangsungnya Pendidikan. Maka bermasyarakat merupakan suatu keniscayaan. Sudah sepatutnya tanggung jawab pendidikan sosial anak amat penting bagi orang tua dan guru dalam mendidik anak agar menjadi anggota masyarakat yang baik. Terdapat banyak sekali konsep pendidikan sosial anak, Salah satu konsep pendidikan sosial untuk anak tertuang dalam kitab Tarbiyah AlAwlad Fi Al-Islam karya Abdullah Nasih Ulwan. Menurut Abdullah Nasih Ulwan, Pendidikan sosial adalah mendidik anak sejak dini untuk komit dengan etika sosial yang baik dan dasar-dasar jiwa yang luhur, yang bersumber dari akidah islam yang abadi dan perasaan iman yang dalam. Dengan demikian si anak dapat hidup di masyarakat dengan pergaulan dan adab yang baik, pemikiran yang matang, dan bertindak secara bijaksana.
\end{abstract}

Kata Kunci: Pendidikan, sosial, Abdullah Nasih Ulwan, Tarbiyah Al-Awlad Fi AlIslam.

\section{PENDAHULUAN}

Manusia sebagai makhluk individu sekaligus makhluk sosial. Manusia mempunyai kebutuhan baik kebutuhan yang bersifat individu maupun kebutuhan yang bersifat sosial sesuai dengan tingkatannya. Kebutuhan-kebutuhan tersebut antara lain yaitu sistem politik, ekonomi, sosial, dan pendidikan. Kebutuhan yang terpenting dibanding dengan kebutuhan lainnya adalah kebutuhan terhadap pendidikan. Hal ini dikarenakan kebutuhan terpenting karena untuk memenuhi kebutuhan - kebutuhan yang lainnya. ${ }^{1}$ Kebutuhan terhadap pendidikan ini merupakan kebutuhan dasar guna memenuhi kebutuhan yang lainnya.

Bapak pendidikan Indonesia merumuskan pendidikan dapat berlangsung di tiga tempat yaitu keluarga, sekolah dan masyarakat atau yang dikenal dengan istilah Tri Pusat Pendidikan.

\footnotetext{
${ }^{1}$ Zakiah Darajat, Ilmu Pendidikan Islam, (Jakarta: Bumi Aksara, 2000), 23.
} 
Selama proses pendidikan ini, anak akan mendapatkan pembimbingan, pembinaan, dan pengarahan secara sadar dan sengaja melalui sistem yang teroganisir.

Pendidikan dapat berlangsung ditengah-tengah masyarakat. Maka bermasyarakat merupakan suatu keniscayaan, baik guru maupun orang tua harus berusaha untuk mempersiapkan generasi selanjutnya kelak menjadi anggota masyarakat yang baik. Oleh karena itu, anak-anak harus dibekali pendidikan yang berlandaskan pada Al-Qur'an dan hadits serta ilmu tentang kemasyarakatan sesuai dengan tahapan atau fase tertentu. Maka setiap fase pertumbuhan merupakan tangga untuk fase berikutnya. seperti contoh seorang anak harus lebih dulu menyesuaikan diri dalam keluarga, sebelum dalam golongan tertentu, kemudian dalam msyarakat yang luas. ${ }^{2}$

Hasil penelitian dan fakta-fakta empiris membuktikan bahwa kekuatan bangunan masyarakat amat bergantung pada individu anggota masyarakat. Dalam ajaran Islam amat mendukung pendidikan anak agar berperilaku baik. Baik perilaku pribadinya maupun perilaku sosialnya. Sehingga apabila mereka setelah memperoleh pendidikan yang baik maka akan terbentuk sikap perilakunya baik. Selanjutnya mereka akan menjadi anggota masyarakat yang baik.

Berdasarkan uraian di atas maka pendidikan sosial kemasyarakatan sangat dibutuhkan. Sedangkan untuk pengertian pendidikan sosial kemasyarakatan adalah pendidikan yang mempersiapkan anak-anak untuk tugasnya sebagai penghasil dan sebagai pemakai. ${ }^{3}$ Pendidikan memegang peranan penting dalam pembentukan sosial anak. Sehingga dengan pendidikan sosial, anggapan yang menyatakan bahwa tingkah laku manusia ditentukan sematamata oleh faktor fisik dan kultural dapat terbantahkan. ${ }^{4}$

Pertanyaan yang muncul selanjutnya adalah bagaimanakah cara mendidik sosial anak? Abdullah Nasih Ulwan menawarkan konsepnya. Menurutnya, Pendidikan sosial adalah mendidik anak sejak dini untuk komit dengan etika sosial yang baik dan dasar-dasar jiwa yang luhur, yang bersumber dari akidah islam yang abadi dan perasaan iman yang dalam. ${ }^{5}$

Pendidikan hendaklah berorientasi pada kemanusiaan sehingga dapat menghormati kepribadian yang telah terbentuk dalam diri anak. Kepribadian atau karakteristik terbentuk sebagai hasil pengasuhan dalam keluarga. ${ }^{6}$

\footnotetext{
2 Zakiah Darajat, Ilmu Jiwa Agama, (Jakarta: Bulan Bintang, 1991), 53.

${ }^{3}$ Solaeman Joesoef, Konsep Dasar Pendidikan Luar Sekolah, (Jakarta : Bumi Aksara, 2004), 91.

${ }^{4}$ Abu Ahmadi, Sosiologi Pendidikan, (Jakarta : Rineka Cipta, 1991), 43.

${ }^{5}$ Abdullah Nasih Ulwan, Tarbiyatul Awlad fi al-Islam Juz 1, (Beirut : Darussalam, t.th), 306-307.

${ }^{6}$ Nusa Putra dan Ninin Dwi Lestari, Penelitian Kualitatif PAUD, ( Jakarta : Raja Grafindo Persada, 2012 ), 34.
} 
Berdasarkan pada uraian di atas, dapat dipahami Abdullah Nasih Ulwan memiliki konsep yang jelas tentang pendidikan sosial anak dan membahas secara khusus dalam kitabnya bab yang menerangkan tentang pendidikan sosial anak. Oleh karena itu penulis berinisiatif untuk mengadakan penelitian dengan judul "Analisis Pendidikan Sosial Anak Perspektif Abdullah Nasih Ulwan Dalam Kitab Tarbiyah Al-Awlad Fi Al-Islam'.

\section{PEMBAHASAN}

\section{Pengertian Pendidikan Sosial Anak}

Pengertian pendidikan dalam ensiklopedi, pendidikan merupakan semua usaha yang secara sadar dilakukan orang dewasa yang bertujuan untuk meningkatkan kedewasaan dan rasa bertanggung jawab atas segala tindakan atau perbuatannya secara moril. ${ }^{7}$ Ngalim Purwanto menjelaskan, pendidikan adalah usaha yang dilakukan untuk mencapai perkembangan jasmani dan rohani ke arah kedewasaan agar berguna bagi dirinya sendiri dan masyarakat. ${ }^{8}$

Sedangkan Hasan Langgulung mendefinisikan pendidikan adalah suatu proses yang mempunyai tujuan untuk menciptakan pola-pola tingkah laku tertentu pada orang yang sedang dididik. Pendidikan di sini mengandung proses yang bertujuan untuk menciptakan pola tingkah laku anak didik, yang diusahakan oleh pendidik. ${ }^{9}$

Sedangkan pengertian dari kata sosial ada beberapa pendapat diantaranya; Kata sosial berasal dari bahasa arab ijtama'a - yajtamiu' - ittima'an yang berarti kumpul atau berkumpul, berbaur, berinteraksi, dan bersosialisasi. Dalam kamus besar bahasa Indonesia kata sosial diartikan suka memperhatikan kepentingan umum, seperti suka menolong, menderma dan sebagainya. ${ }^{10}$ Menurut Sahal Mahfudh, mengartikan kata sosial adalah segala sesuatu yang berkaitan dengan masyarakat yang menyangkut berbagai fenomena hidup dan kehidupan orang banyak, baik dilihat dari sisi mikro individual dan makro kolektif. ${ }^{11}$

Pengertian anak yaitu secara etimologi adalah turunan yang kedua, manusia yang masih kecil. Pengertian anak secara terminologi anak adalah seorang yang belum mencapai kedewasaan dan tergantung secara alami kepada lingkungannya. ${ }^{12}$ Pengertian

\footnotetext{
${ }^{7}$ Soegarda Poerbakawatja, Ensiklopedi Pendidikan, (Jakarta: Gunung Agung, 1982), 257.

${ }^{8}$ M Ngalim Purwanto, Ilmu Pendidikan Teoritis dan Praktis, (Bandung: PT Remaja Rosdakarya, 2000), 11

${ }^{9}$ Hasan Langgulung, Azas-Azas Pendidikan Islam, (Bandung: al-Husna,1988), hlm 189

${ }^{10}$ Tim Penyusun Kamus Pusat Pembinaan dan Pengembangan Bahasa Departemen Pendidikan dan Kebudayaan, Kamus Besar Bahasa Indonesia (Jakarta: Balai Pustaka,1993), 53.

${ }^{11}$ M.A. Sahal Mahfudh, Nuansa Fiqih Sosial (Yogyakarta: Pustaka Pelajar, 1994), 257.

${ }^{12}$ W.J.S. Poerwadarminta, Kamus Umum Bahasa Indonesia, (Jakarta: Balai Pustaka, 1985), 38.
} 
anak secara biologis adalah makhluk ciptaan Allah yang mengalami pertumbuhan dan perkembangan yang berlangsung secara evolutif yaitu melalui proses bertahap, dimana anak mengalami tahapan tumbuh dan berkembang menjadi manusia dewasa. ${ }^{13}$

Secara psikologi anak berarti makhluk yang dikaruniai mental dan emosional. Yang harus disadari adalah anak belum mengatur dan mengendalikan ledakan emosi sebab perkembangan jiwanya belum sempurna. Karena anak membutuhkan perhatian, bimbingan, dan kasih sayang orang tua. Hal ini akan sangat menentukan bagi perkembangan anak di masa depan. Anak merupakan makhluk yang ingin tahu segala hal. Anak sedang berproses mempelajari perilaku sosial sebagai persiapan bagi kehidupan sosial yang lebih tinggi. ${ }^{14}$

Anak secara psikologis akan menyesuaikan dengan lingkungan dan melakukan tugas tertentu. Ada banyak tugas yang harus dilatihnya agar mampu melakukan adaptasi sosial dan mampu mempertahankan keberlangsungan hidupnya. Secara sosiologis anak adalah makhluk sosial yang senantiasa berinteraksi dengan anggota masyarakat. Dia tidak hidup sendiri melainkan hidup bersama ayah dan ibunya dalam lingkup sosial kecil, yakni keluarga. Di luar keluarga anak juga berhubungan dengan anggota masyarakat yang lain. ${ }^{15}$

Berdasarkan beberapa pengertian diatas, dapat disimpulkan bahwa Pendidikan adalah segala usaha yang dilakukan dengan sadar baik berupa pengaruh, bimbingan, atau arahan yang dilakukan orang dewasa kepada anak agar menjadi orang yang dewasa, mandiri dan memiliki kepribadian yang utuh dan matang. ${ }^{16}$ Pendidikan sosial di sini adalah pendidikan tentang etika sosial dalam bermasyarakat sehingga seseorang bisa menjadi anggota masyarakat yang baik. ${ }^{17}$

Bentuk pendidikan sosial dapat berupa bimbingan dan arahan atau segala usaha yang dilakukan secara sadar, terencana, sistematis, berlangsung secara terus menerus untuk mewujudkan suasana belajar dan proses pembelajaran agar peserta didik mampu mengembangkan potensi dirinya. Potensi yang dapat dikembangkan adalah kepribadian, kecerdasan, pengendalian diri, akhlak mulia, serta keterampilan yang diperlukan dirinya, masyarakat, bangsa, dan negara. ${ }^{18}$

\footnotetext{
${ }^{13}$ Jalaluddin, Teologi Pendidikan, (Jakarta: Raja Grafindo Persada, 2001), 128.

${ }^{14}$ Elizabeth Hurlock, Psikologi perkembangan Anak, (Jakarta: Erlangga, 1991), 108.

${ }^{15}$ Kartini Kartono, Psikologi Anak, (Bandung: Alumni, 1982), 84.

${ }^{16}$ Yudrik Jahya, Wawasan Kependidikan, (Jakarta: Depdiknas,2004), 2.

${ }^{17}$ Nurseno, Sosiologi, (Solo: Tiga Serangkai Mandiri, 2004), 2.

${ }^{18}$ Yudrik Yahya, Wawasan Kependidikan, (Jakarta: Depdiknas, 2004), 2.
} 
Abdullah Nasih Ulwan memiliki konsep pendidikan yaitu dengan menanamkan dasar-dasar kejiwaan yang mulia. Hal ini dikarenakan Islam memiliki pedoman dalam mendidik jiwa setiap masyarakat, baik anak-anak maupun orang dewasa. Pembentukan kepribadian Islam tidak akan sempurna kecuali dengan jalan penanaman dasar-dasar kejiwaan yang mulia. ${ }^{19}$

Untuk mewujudkan pendidikan sosial menjadi lebih sempurna, Islam telah membuat bimbingan yang praktis dan mudah untuk dipraktekkan. Diharapkan masyarakat dapat tumbuh dan berkembang atas dasar kerja sama yang produktif, ikatan yang kuat, sopan santun yang luhur, saling mencintai dan kritik diri yang konstruktif.

Bukan hal yang mudah dalam mendidik dan membentuk perilaku seperti yang diuraikan di atas sehingga membutuhkan metode dan strategi yang tidak tunggal. Di dalamnya harus ada pengalaman, keteladanan dan interaksi sosial yang dapat digunakan sebagai strategi utama. Strategi apapun yang dipilih seyogyanya menempatkan tumbuh kembang kesadaran anak tentang dirinya menuju kematangan dan kedewasaan merupakan tujuan utamanya.

\section{Latar belakang Abdullah Nasih Ulwan mengarang kitab Tarbiyah al-Awlad fi al-} Islam

Kitab Tarbiyah al-awlad fi al-Islam adalah salah satu karya beliau yang mendapat apresiasi yang sangat tinggi dari banyak kalangan. Utamanya, para ilmuwan dan cendikiawan.

Latar belakang Syeikh Abdullah Nasih Ulwan mengarang kitab ini ada lima. Diantaranya; Pertama, kepustakaan Islam amat miskin dari refrensi mengenai pendidikan anak menurut Islam. Kedua, Adanya pengakuan para cendekia. Baik para cendekiawan Islam atau barat mengenai ajaran Islam yang abadi dan aturan yang tinggi. Bahwa dalam Islam mempunyai nilai tertinggi dan memberikan solusi bagi kehidupan yang berbeda, oleh karnanya Abdullah Nasih Ulwan perlu menulis buku ini yang menjelaskan secara lengkap pendidikan menurut Islam. Ketiga, mengingat tujuan utama dalam dakwah Islam untuk membentuk manusia, bukan untuk mencetak manusia yang hanya dapat memberi nasehat. Tapi membina hati. Berubahnya iman kepada Islam menjadi perbuatan. Keempat, keprihatinan beliau dengan perpecahan dan pertengkaran

\footnotetext{
${ }^{19}$ Abdullah Nasih Ulwan, Tarbiyatul Awlad fi al-Islam Juz 1, (Beirut : Darussalam, t.th), 306-307.
} 
umat Islam. Kelima, pendidikan anak merupakan salah satu bagian dari pendidikan individu yang diajarkan Islam. ${ }^{20}$

Abdullah Nasih Ulwan adalah pemikir Islam orisinal, konsep pemikirannya tertuang dalam karya besarnya, Tarbiyah al-Awlad fi al-Islam. Di dalamnya penjelasan dalam menanamkan nilai kepribadian dan etika atau moral dalam anak. Selain nilai agama dan nilai moral, di dalamnya juga terdapat mengenai nilai pendidikan sosialnya. ${ }^{21}$

\section{Karakteristik Pemikiran Abdullah Nasih Ulwan}

Setting sosio kultural, politik dan keagamaan yang selalu berkembang bisa mempengaruhi karakteristik pemikiran seseorang. Hal ini menimbulkan pendapat yang berbeda pula. Sehingga antara ciri khas sebuah pemikiran dengan keadaan sosial memiliki hubungan yang sangat erat. Di samping keadaan sosio kultural, politik dan keagamaan yang selalu berkembang, pengalaman pribadi seseorang juga dapat mempengaruhi pemikiran tersebut.

Berdasarkan uraian Hasan Langgulung, kitab Tarbiyah al-awlad fi al-Islam dapat digolongkan pada corak pemikiran yang berdiri sendiri dan berbeda dari ketiga corak sebelumnya. Kitab ini semata-mata memuat tentang pendidikan menurut Islam bagi anak secara lengkap.

Dalam penelusuran penulis, ciri khas yang paling menonjol dalam kitab Tarbiyah al-awlad fi al-Islam karya Syekh Abdullah Nasih Ulwan ini adalah dalam penulisannya. Dalam tiap bab di kitab ini ditulis secara rinci disertai dengan dalil naqli, baik dari alQur'an dan Hadist. Disertai dengan kisah dari para pendahulu, Para salafus sholihin dan disertai dengan beberapa pendapat ulama' yang lain. Hal ini seakan memberikan penegasan bahwa apa yang ditulis oleh Abdullah Nasih Ulwan dalam kitab ini merupakan pemikiran orisinil dari Islam itu sendiri tanpa disertai pemikiran dari Ilmuwan barat. Kitab ini disusun dengan rinci, dengan berbagai point yang menjadi tema pokoknya sekaligus dilengkapi dengan solusi-solusi dan langkah-langkah ke depan yang lebih baik.

\section{Analisis pendidikan sosial anak perspektif Abdullah Nasih Ulwan Dalam Kitab}

\section{Tarbiyah al-awlad fi al-islam}

Pemikiran Abdullah Nasih Ulwan tentang pendidikan sosial anak dalam kitab Tarbiyah al-Awlad fil al-Islam. Yaitu :

a. Pendidikan penanaman dasar-dasar kejiwaan yang mulia

\footnotetext{
${ }^{20}$ Abdullah Nasih Ulwan, Tarbiyah...xv-xxiii

${ }^{21}$ http:॥Tarbiyah Pewaris- Bibliografi Syeikh Dr. Abdullah Nasih Ulwan.htm.
} 
Menurut Nashih Ulwan, cara/upaya menanamkan dasar-dasar kejiwaan yang mulia sejak dini pada anak didik dapat dilakukan dengan model pendidikan penanaman dasar-dasar kejiwaan yang mulia dalam rangka membentuk pribadi anak agar mempunyai pribadi yang luhur, hal-hal yang ditanamkan yaitu:

1) Takwa

Seorang mukmin yang bertakwa kepada Allah akan merasa takut kepada Allah dan merasa diawasi oleh-Nya adalah sumber keutamaan dalam bersosial. Di samping itu dengan takwa dapat menghindarkan seseorang dari kerusakan, kejahatan, dosa-dosa dan sebagainya. Takwa adalah menjalankan apa yang diperintah oleh Allah dan menjauhi larangannya. ${ }^{22}$

Dari penjelasan tersebut jelas bahwa takwa merupakan dasar yang paling penting yang harus ditanamkan pada jiwa anak. Hal ini dikarenakan yang menentukan mulia tidaknya derajat seseorang disisi Allah adalah taqwa.

2) Persaudaraan sesama muslim

Abdullah Nasih Ulwan dalam Kitab Tarbiyah al-Awlad fi al-Islam menyatakan Ukhuwah Islamiyah adalah ikatan kejiwaan yang melahirkan perasaan yang mendalam dengan kelembutan, cinta dan sikap hormat kepada setiap orang yang sama-sama diikat dengan akidah Islamiah, iman, dan takwa. ${ }^{23}$

Quraish Shihab mengatakan makna sesama muslim tidak hanya ditentukan oleh kesamaan iman, melainkan juga dijalin oleh persaudaraan seketurunan. Islam mengajarkan kepedulian kepada masalah sosial kemanusiaan sama pentingnya dengan ibadah kepada Allah. ${ }^{24}$ Sehubungan dengan hal ini Allah telah berfirman;

Artinya: "Sesungguhnya orang-orang beriman itu bersaudara. sebab itu damaikanlah (perbaikilah hubungan) antara kedua saudaramu itu dan takutlah terhadap Allah, supaya kamu mendapat rahmat.” (Q.S. alHujuraat: 10).

3) Kasih sayang

\footnotetext{
${ }^{22}$ Hafidz Hasal Al-Mas'udi, Taisirul Khollak (Surabaya: Al-hidayah, t.t), 4.

${ }^{23}$ Abdullah Nashih Ulwan, Tarbiyah al-Awlad fi al-Islam, Juz 1 (Beirut: Dar al-Salam, t.th), 276

${ }^{24}$ Shihab Quraish, Wawasan Al-Qur'an : Tafsir Maudhu'I atas perbagai Persoalan Umat (Bandung: Mizan, 1998), 490-491
} 
Kasih sayang adalah perasaan halus di dalam hati, kelembutan dalam sanubari, dan kepekaan perasaan simpati kepada orang lain. Abu Bakar Shiddiq ketika berpesan dan memberi wasiat kepada sekelompok pasukan Usamah bin Zaid, berkata:

4) Mengutamakan orang lain

Mengutamakan orang lain dari pada diri sendiri dalam kebaikan dan kepentingan pribadi yang bermanfaat. Itsar adalah perangai yang baik selama bertujuan mencari keridhaan Allah. Sikap ini merupakan dasar kejiwaan yang menunjukkan kejujuran iman, kejernihan sanubari, dan kesucian diri. Disamping itu, ia juga merupakan penopang utama dalam mewujudkan jaminan sosial dan perwujudan jaminan sosial dan perwujudan kebaikan bagi anak manusia. $^{25}$

5) Memaafkan

Memaafkan ialah perasaan jiwa yang bersikap toleran meski lawannya orang zalim yang sudah melampaui batas pada saat ia mampu membalas dendam bila ia menghendakinya. Sikap tidak pemaaf merupakan kehinaan dan kerendahan. Maaf merupakan moral dasar yang membuktikan kemantapan iman dan tingkah laku islam yang tinggi. Salah satu ayat yang menjelaskan tentang maaf adalah Q.S. Fushilat:34.

6) Berani karena benar

Berani adalah kekuataan jiwa seorang mukmin yang disebabkan oleh iman kepada Allah, dari kebenaran yang disadari, dari tanggung jawab yang dia rasakan, dan dari pendidikan yang di jalani.

Nasih Ulwan berpendapat, intelektual yang tinggi saja tidak cukup untuk menghindarkan seseorang dari perbuatan yang menyimpang dan belum menjamin seseorang menjadi manusia yang memiliki hubungan yang baik dengan sesamanya. Akan tetapi, dasar-dasar kejiwaan yang diajarkan Islam sangat perlu ditanamkan pada diri anak didik, sehingga anak didik akan terhindar dari hal-hal yang menyimpang di tengah-tengah masyarakat.

Hal ini mempunyai kemiripan dengan pemikiran Hasan al-Bannah yang mengatakan untuk proses pendidikan sosial (tarbiyah ijtima'iyah). Langkah pertama adalah mengubah seseorang (anak didik) dari statusnya sebagai

${ }^{25}$ Abdullah Nashih Ulwan, Tarbiyah al-Aulad fi al-Islam, hlm. 280 
individu menjadi sebuah pribadi. Langkah kedua membentuk individu menjadi berkarakter sosial. Pada dasarnya tujuannya adalah internalisasi nilai-nilai yang mulia sehingga dapat membentuk kepribadian yang mulia pada diri anak didik adalah hal yang ingin di capai. ${ }^{26}$

Berdasarkan uraian di atas, maka penanaman dasar-dasar kejiwaan ini mempunyai peran yang sangat penting dalam pekembangan anak didik. Sebaliknya bila penanaman dasar-dasar kejiwaan ini diabaikan maka akan berdampak sangat buruk pada perkembangan anak didik dalam kehidupan bermasyarakat.

b. Pendidikan memelihara hak orang lain

Beberapa hal tentang hak sosial orang lain meliputi: hak orang tua, hak tetangga, hak guru, hak teman, hak orang dewasa.

1) Hak kedua orang tua

Berikut ini beberapa wasiat Nabi SAW dalam masalah berbakti kepada orang tua; Pertama, Ridha Allah berada dalam keridhaan kedua orang tua. Kedua, Berbuat baik kepada keduanya lebih diutamakan dari pada jihad fi sabilillah. Ketiga, Mendoakan mereka setelah tiada dan memuliakan teman dekatnya. Keempat, Mendahulukan bakti kepada ibu terlebih dahulu kemudian kepada bapak. Kelima, memperingatkan anak-anak terhadap perbuatan durhaka. Keenam, Adab berbakti kepada kedua orang tua.

Bagi para pendidik hendaknya mengajarkan kepada anak-anak tentang adab-adab bergaul dengan ayah dan ibunya. Contohnya sesuai dengan firman Allah dalam Q.S. al-Israa':24.

2) Hak kerabat

Ada beberapa faidah dari silaturahmi. Pertama, menghubungkan persaudaraan adalah salah satu manifestasi iman kepada Allah dan hari akhir. Kedua, dapat memanjangkan umur dan memperluas rezeki. Ketiga, dapat menjaga pelakunya dari kematian yang buruk. Keempat, dapat memakmurkan rumah dan mengembangkan harta. Kelima, mengampuni dosa dan menghapus kesalahan. Keenam, memudahkan jalan perhitungan amal. Berkenaan dengan hak saudara ini Allah berfirman yang artinya:

\footnotetext{
${ }^{26}$ Utsman Abdul Mu'iz Ruslan, Pendidikan Politik Ikhwanul Muslimin, (Solo: Era Intermedia, 2000), 25.
} 
Hai sekalian manusia, bertakwalah kepada Tuhan-mu yang telah menciptakan kamu dari seorang diri, dan dari padanya. Allah menciptakan isterinya; dan dari pada keduanya Allah memperkembang biakkan laki-laki dan perempuan yang banyak. Dan bertakwalah kepada Allah yang dengan (mempergunakan) nama-Nya kamu saling meminta satu sama lain, dan (peliharalah) hubungan silaturrahim. Sesungguhnya Allah selalu menjaga dan mengawasi kamu. (Q.S. an-Nisa': 1).

3) Hak tetangga

Hak-hak tetangga menurut pandangan Islam intinya terletak pada empat hal: tidak menyakiti tetangga, melindunginya dari orang-orang yang berbuat jelek, bermuamalah dengan baik, serta membalas kejahatannya dengan kelembutan dan pemaafan.

4) Hak guru

Berdasarkan wasiat-wasiat Nabi SAW ada beberapa hak guru sebagai berikut:

a) Hendaknya seorang siswa bersikap tawaduk kepada gurunya, tidak menyelisihi pendapat dan arahannya.

b) Hendaknya seorang murid melihat gurunya dengan hormat dan menyakini bahwa gurunya mempunyai kedudukan yang sempurna, karena, hal itu memudahkan baginya dalam mengambil manfaat dari gurunya.

c) Seorang murid harus mengetahui kewajibannya terhadap guru dan tidak melupakan jasanya.

d) Bersikap sabar kepada gurunya yang bersikap keras dan kasar. Murid seharusnya tidak menjadikan perangai keras tersebut sebagai penghalang dalam mengambil manfaat darinya.

e) Hendaknya seorang murid duduk sopan di depan guru dengan bersikap tenang, tawaduk, dan penuh penghormatan.

f) Seorang murid tidak boleh masuk ke ruang khusus bagi gurunya kecuali dengan ijinnya, baik gurunya sedang sendirian maupun bersama orang lain.

g) Apabila seorang murid mendengarkan gurunya menyebutkan dalil sebuah hukum, suatu hal yang bermanfaat, menceritakan sebuah kisah atau mendendangkan sebuah syair hafalannya, dengarkanlah dengan penuh perhatian, merasa butuh dan gembira seakan-akan dia belum pernah mendengarkannya.

Itulah beberapa adab yang harus diajarkan para pendidik kepada anak didiknya. Adab-adab tersebut merupakan pembelajaran yang mulia dan hak 
bermasyarakat yang baik, ketika anak sudah terdidik dengan adab dan hak-hak tersebut sejak dini, mereka akan melaksanakan kewajiban yang harus ditunaikan kepada orang-orang yang harus ditunaikan kepada orang yang telah memberi ilmu dan membimbing mereka dalam membentuk kepribadian yang mulia, para guru dan pendidik.

5) Hak Teman

Para guru dalam mendidik anak wajib memperhatikan hal yang sangat penting dalam memilihkan teman yaitu teman yang beriman dan shalih untuknya. Karena, teman yang shalih mempunyai pengaruh yang besar dalam menjaga anak agar tetap istiqamah, shalih, dan urus akhlaknya.

Adapun hak-hak teman yang harus ditunaikan yaitu: Mengucapkan salam ketika bertemu, mendoakannya ketika bersin, mengunjunginya karena Allah, menolongnya ketika susah, memenuhi undangannya apabila diundang dan saling memberi hadiah pada waktu-waktu tertentu.

6) Hak orang yang lebih tua

Diantara hak orang yang lebih tua yaitu; menghormati orang yang lebih tua, mendahulukan orang yang lebih tua dalam segala urusan, mengingatkan anak kecil yang meremehkan orang yang lebih tua.

Memelihara hak-hak sosial adalah merupakan sebuah kewajiban dalam upaya membentuk anak didik yang mempunyai sikap sosial yang positif dalam lintasan kehidupan bermasyarakat, dan juga tentunya disertai dengan dasar-dasar kejiwaan yang mulia.

c. Pendidikan disiplin etika sosial

Menurut Nasih Ulwan, mengamalkan etika sosial adalah upaya dengan cara membiasakan pada anak didik sejak dini untuk beretika dalam kehidupan individu bermasyarakatnya yang perlu dibiasakan oleh pendidik kepada anak didiknya.

Adapun hal-hal yang perlu dibiasakan pada anak didik yaitu menyangkut tentang kehidupan sehari-hari, contoh: etika makan minum, mengucapkan salam, masuk izin rumah, etika duduk dalam pertemuan, etika berbicara, bergurau, mengucapkan selamat, etika menjenguk orang sakit, etika melayat (ta'ziyah) dan etika bersin dan menguap.

d. Pendidikan kontrol dan kritik sosial

Nasih Ulwan berpendapat bahwa dalam membentuk tingkah laku anak adalah dengan cara membiasakan anak didik sejak dini untuk melakukan kontrol dan 
kritik sosial, membina setiap orang yang bergaul dengannya dan memberi nasehat kepada orang yang menyimpang dari etika Islam.

Nasih Ulwan menjelaskan pembiasaan kontrol sosial pada anak tidak akan berjalan dengan baik manakala anak belum dibiasakan untuk melakukan kritik sosial dengan semangat amar makruf nahi munkar (menyuruh kebaikan dan mencegah keburukan), sehingga anak peka terhadap keadaan sosial dan bisa mengadakan kontrol dengan baik.

\section{Kesimpulan}

Pendidikan sosial anak yang ditawarkan oleh Abdullah Nasih Ulwan tidak hanya berisi teori saja akan tetapi juga sangat memperhatikan prakteknya dalam kehidupan sehari-hari. Karya Abdullah Nasih Ulwan ini merupakan gambaran langkah yang sifatnya konkrit sehingga diharapkan bisa memudahkan dalam mengimplementasikan dalam konteks kehidupan seharihari. Nasih Ulwan berpendapat ada empat hal pokok dalam pendidikan sosial anak. Yaitu; Menanamkan mentalitas yang luhur, Memperhatikan hak-hak orang lain, Komitmen pada etika sosial secara umum, pengawasan kritik dan sosial.

\section{DAFTAR PUSTAKA}

Ahmadi, Abu. 1991. Sosiologi Pendidikan. Jakarta : Rineka Cipta.

Darajat, Zakiah. 1991. Ilmu Jiwa Agama. Jakarta: Bulan Bintang. 2000. Ilmu Pendidikan Islam. Jakarta: Bumi Aksara.

Hurlock, Elizabeth. 1991. Psikologi perkembangan Anak. Jakarta: Erlangga.

Jahya, Yudrik. 2004. Wawasan Kependidikan. Jakarta: Depdiknas.

Jalaluddin. 2001. Teologi Pendidikan. Jakarta: Raja Grafindo Persada.

Joesoef, Solaeman. 2004. Konsep Dasar Pendidikan Luar Sekolah. Jakarta: Bumi Aksara.

Kartono, Kartini. 1982. Psikologi Anak. Bandung: Alumni.

Langgulung, Hasan. 1988. Azas-Azas Pendidikan Islam. Bandung: al-Husna.

Mahfudh, M.A. Sahal. 1994. Nuansa Fiqih Sosial. Yogyakarta: Pustaka Pelajar.

Nurseno. 2004. Sosiologi. Solo: Tiga Serangkai Mandiri.

Poerbakawatja, Soegarda. 1982. Ensiklopedi Pendidikan. Jakarta: Gunung Agung. 
Poerwadarminta, W.J.S. 1985. Kamus Umum Bahasa Indonesia. Jakarta: Balai Pustaka.

Purwanto, M Ngalim. 2000. Ilmu Pendidikan Teoritis dan Praktis. Bandung: Remaja Rosdakarya.

Putra, Nusa dan Ninin Dwi Lestari. 2012. Penelitian Kualitatif PAUD. Jakarta : Raja Grafindo Persada.

Quraish, Shihab. 1998. Wawasan Al-Qur'an : Tafsir Maudhu'I atas perbagai Persoalan Umat. Bandung: Mizan.

Ruslan, Utsman Abdul Mu'iz. 2000. Pendidikan Politik Ikhwa nul Muslimin. Solo: Era Intermedia.

Tim Penyusun Kamus Pusat Pembinaan dan Pengembangan Bahasa Departemen Pendidikan dan Kebudayaan. 1993. Kamus Besar Bahasa Indonesia. Jakarta: Balai Pustaka.

Ulwan, Abdullah Nasih. t.th. Tarbiyatul Awlad fi al-Islam Juz 1. Beirut : Darussalam. 